\title{
Emotional Intelligence and Service Quality: An Empirical Study of Pakistani Telecommunication Sector
}

\author{
${ }^{1}$ Muhammad Rizwan Basharat, ${ }^{2}$ Naintara Sarfraz Raja \\ ${ }^{I}$ Foundation University Institute of Engineering \& Management Sciences, New Lalazar, Rawalpindi Cantt. \\ Pakistan. \\ ${ }^{2}$ Assistant Professor Foundation University Institute of Engineering \& Management Sciences, New Lalazar, \\ Rawalpindi Cantt. Pakistan.
}

\begin{abstract}
The role of this study is to investigate the relationship between emotional intelligence and service quality. The data was collected from the telecommunication sector of Pakistan through questionnaires. The total sample of the respondents in the study was 400 but we had received only 250. Convenience sampling was used to collect the data from respondents. The result showed that the emotional intelligence is the positive predictor of the service quality.
\end{abstract}

Keywords: Emotional intelligence, Service quality.

\section{Introduction}

Telecommunication sector is one of the most important sectors of any economy and its contribution remains the greatest to the GDP of the economy (Ahluwalia, 1998). The telecom organizations are providing the competitive services by catering the smallest needs of the customers. In telecom sector, service quality is the key driver of profitability. Better service quality in the Telecom sector leads towards customer loyalty (Heskett et al, 1997).

Unlike manufacturing sector, the products and services offered in the telecomm are almost the same and it becomes difficult to create differentiation. Hence, the organization that become successful in providing higher service quality succeeds in the long run. It is the higher level of service quality that is required by the telecom sector in order to compete and then eventually become the market leader.

Service quality is determined by many variables. Emotional intelligence is one of the most important determinants of service quality. It has emerged as one of the valuable disciplines in the modern era of business. As the service providers are required to be receptive and adaptive towards the demands and behaviors of the customers, it is basically emotional intelligence that helps managers in responding effectively towards the customers.

In telecom industry the most important ingredient which is considered as a back bone of service providers is emotional intelligence because it can easily translated their interpersonal, intrapersonal and technical skills. Due to the practice of these services providers can augment their skill which will help in customer satisfaction. In this competitive era the telecom industry has the best source to utilize the emotional intelligence, hence resulting the customer satisfaction.

The term emotional intelligence is explained by itself that it deals with the emotions of the human being. So the research is important because the human perspective is involved which is more important in today's business world, every business is now customer oriented so they have to put all their efforts to make their customers satisfied. So in this research we will study the emotional intelligence with service quality and resulting the impact on customer satisfaction. Because of if the firms provide the better quality services to the customer then their revenues will definitely high. The topic selection is in a sense the to check that how companies give importance to the customer satisfaction and are they using emotional intelligence in their services?

Regarding the service industry, the most important thing is to offer better services to customers. Besides making relevant procedures and standard operations, the service quality is taken for an important portion. Organization can increased the knowledge regarding customer by using emotional intelligence which will further enhance their ability to recognize and regulate the customer needs.

\section{Emotional Intelligence and Service Quality "Impact on each other"}

From the empirical evidence we concluded that to being a successful organization you have to create a climate of quality service (Schneider and Bowen, 1993; Schneider et al, 1998). Thus this climate of service helps in achieving and enhancing quality in the services and hence the complex process of service quality is attained. The climate of service at individual (employee) level is manifested by the concerns for customers and the practices and behaviors that are expected by management from the customers. 
The quality of services can be practiced in the organizations by the reinforcement and implementation of appropriate behavior by the employee. These climates are further enhanced by employee empowerment, and through clean the hurdle such as unsuitable HR policies and preventive management style, etc.

Hence, the concept of emotional intelligence can be used in the organizations that contain key competencies for creating and maintaining the quality of services in the organizations. Emotional intelligence talks about relationship between thoughts, behaviors and feelings. It can be determined as a measure of the degree to which a person that to what extent he has the ability to perceive, understand and regulate the emotions of other people and amalgamate their thoughts and actions.

This ability has been described as emotional intelligence. By maintaining emotional intelligence, managers become able to get greater self-understanding, demonstrate better health, morale and quality of work life, and develop closer working relationships. It is vital for organizational leaders to recognize the significance of emotionally intelligent behavior, and to actively reward it. The effectiveness of the service oriented companies will be enhanced if the environment is positively reinforced with emotional intelligence, hence resulting in the provision of quality services to the customers.

\section{Objectives of Study:}

The objectives of the research are:

- To study emotional intelligence that act as a predictor of higher service quality in the Telecom sector

- To study service quality that is influenced by emotional intelligence.

- To investigate the use of emotional intelligence that leads to higher service quality.

\section{Literature Review}

In the current chapter, the previous researches have been associated with the recent study in order to generate authenticity and a link between the previous and recent arenas of knowledge.

Slaski and Bardzil (2003) talk about implementation of emotional intelligence skills in service sector. According to them, emotional intelligence is necessary in creating and maintaining the climate of service in the organization.

Susan and Pappas (2007) linked emotional intelligence with increased performance to organizations in service sector. According to them emotional intelligence has many implications for the selection and development of employees and for enhancing service quality. Research has concluded with the fact that if employees use the skills of emotional intelligence effectively.

Schneider and others (1980) exclaimed the perceptions of employees and customers regarding the services provided by the banks were discovered. Results reflected a strong relationship between employee perceptions of branch practices and methods of service quality of customer perception.

Kiely (2005) conducted her research on the role of service providers in service delivery and explored the relationship between emotional intelligence and service quality through the study of cargo services in United Kingdom. The results revealed that offering the cargo services is complex and the potential for problems and unexpected happening is high. Hence, service providers build up and maintain relationships with customers through mutual trust, understanding and cooperation.

Kernbach and Schutte (2005) research suggested that higher emotional intelligence displayed by the service provider in the video clip led to greater customer satisfaction when transacting services. Deadrick and MacAfee (2001) have discovered that many organizations are trying to improve the level of services in the organizations by exhibiting the necessary emotions and understanding the emotions of the others.

Varca (2004) in his research finding found that service workers can learn service skills with the help of emotional intelligence. He conducted his research on service organization. The research was concluded by the finding that these skills were based on emotional intelligence and were rated important for job success.

In hospitality industry, Langhorn (2008) conducted a study in which concluded that the practice of emotional intelligence skills by the general managers has a positive impact on team performance that ultimately result in better services offered to the customers as the interaction between frontline employees and the customers is at its maximum.

Cavelzanl and others (2005) extended the scope of study in hospitality industry and studied the relationship between emotional intelligence and service quality. The paper concludes that if emotional intelligence is learned and implemented successfully, it can lead to better level of services in the hospitality industry.

Hence, it can be found that emotional intelligence can be related with the services quality in the Telecom sector and positive results can be withdrawn.

\section{Hypothesis:}

H1: Emotional intelligence has a relationship with service quality.

Ho: Emotional intelligence has no a relationship with service quality. 


\section{Study Area:}

\section{Methodology}

In this research study, we will selected five telecommunication companies (i.e: Mobilink, Zong, Telenor, Warid, Ufone. The study area is limited to the study of emotional intelligence skills practiced by employees and its impact on delivering services to the customers. The researcher is interested in investigating the relationship between emotional intelligence and service quality. In the study, the total sample size will be 250 respondends. In order to collect data from the telecom sector, two separate questionnaires will be used. The two questionnaires are based upon two variables. The service quality SERVQUAL model was developed for independent variable by Zeithaml in 1985 which is being adopted for this reacher .for emotional intelligence questionnaires is being adopted which was developed by Hay group (2002). In this paper questionnaire is used to collect the data; the questionnaire consists of 5 points Likert Scale starting from strongly disagree to strongly agreed $(1-5)$.

\section{Procedure:}

The aim of the research was to empirically study the telecom sector of Pakistan. The two variables were studied i.e. emotional intelligence and service quality. For emotional intelligence, emotional intelligence inventory based on 16 questions was used and hence emotional intelligence was measured from the employees of the Telecom Sector. The data was collected through primary source that is questionnaire.

\section{Regression and Correlation:}

The collected data was quantified by using regression analysis and correlation. Tables were used to analyze the findings of the data collected.

Table 1

\begin{tabular}{|c|l|l|l|l|l|}
\hline $\begin{array}{c}\text { Telecom } \\
\text { Companies }\end{array}$ & R & \multicolumn{1}{|c|}{ R Square } & Adjust Square & F Statistics & P Value \\
\hline Mobilink & 0.822 & 0.653 & 0.647 & 25.351 & 0.000 \\
\hline Ufone & 0.652 & 0.551 & 0.543 & 13.352 & 0.000 \\
\hline Telenor & 0.321 & 0.581 & 0.573 & 9.254 & 0.001 \\
\hline Waird & 0.452 & 0.098 & 0.081 & 11.698 & 0.000 \\
\hline Zong & 0.214 & 0.059 & 0.043 & 3.842 & 0.001 \\
\hline
\end{tabular}

\section{R value:}

$\mathrm{R}$ value elucidates the coefficient of correlation between emotional intelligence and service quality in telecom sector. In case of Mobilink and Ufone the $\mathrm{R}=0.822$ and 0.652 respectively which indicates that there is a strong relation between these variables. But if we see the Telenor, Warid and Zong $\mathrm{R}=0.321,0.452$ and 0.214 respectively, which shows that there is weak relationship between these variables.

$\mathbf{R}^{2:}$

$\mathrm{R}^{2}$ is the coefficient of determination, in case of Mobilink, Ufone, Telenor, WArid and Zong it indicates that $65.3 \%, 0.551 \%, 0.581 \%, 0.098 \%$ and $0.059 \%$ variation in the service quality is because of emotional intelligence respectively and only $35.7 \%, 0.994 \%, 0.944 \%, 0.999 \%$ and 0.999 is explained by the residuals. Whereas, Adjusted R square value of Mobilink, Ufone, Telenor, Warid and Zong are 0.647, 0.543, 0.573, 0.081, and 0.043 respectively indicating the adjustment in $\mathrm{R}^{2}$ to reflect the reality.

\section{F Statistics:}

F Statistics shows that how much the model is fit and accurate, the results shows that the model fitted is fairly accurate.

P Value:

The $\mathrm{p}$ value in case of all the companies is $0.000<0.05$ showing that null hypothesis of all the telecom companies have been rejected.

\section{Correlation:}

To check the Correlation between emotional intelligence of the employees of Mobilink, Ufone, Telenor, Warid and Zong with the dimensions of service quality and following results are gathered:

\section{$\underline{\text { Table } 2}$}

Correlation

\begin{tabular}{|c|l|l|l|l|l|}
\hline \hline Companaies & Tangibles & Reliability & Responsiveness & Empathy & Assurance \\
\hline Mobilink & 0.720 & 0.720 & 0.720 & 0.720 & 0.776 \\
\hline Ufone & 0.632 & 0.632 & 0.685 & 0.632 & 0.612 \\
\hline Telenor & 0.235 & 0.458 & 0.552 & 0.245 & 0.336 \\
\hline Warid & 0.523 & 0.521 & 0.523 & 0.245 & 0.254 \\
\hline Zong & 0.305 & 0.221 & 0.124 & 0.708 & 0.708 \\
\hline
\end{tabular}


The result shows that all the companies are correlated with each other in respect of emotional intelligence and service quality dimensions.

\section{Conclusion}

From the above discussion and empirical evidences it is concluded that emotional intelligence is the positive predictor of service quality dimensions of Pakistan telecommunication sector. As per the results, it is indicating that the $\mathrm{H} 1$ hypothesis is accepted which means emotional intelligence is the positive predictor of service quality. If the companies are using emotional intelligence at workplace and offer better services to customers than the performance of the company will enhance and overall image of the company will get stronger. Empirically, it is concluded that the organizations who are using emotional intelligence offers far better services than those companies who do not use the emotional intelligence skills at work place.

\section{Limitations:}

- The sample size of the research was small i.e. two hundred and forty which was not representative of the whole population.

- Time and resources were limited so a comprehensive study was not conducted.

- For conducting research on the same topic in future, more Telecom companies should be included and emotional intelligence of employees should be studied at every level of the organization.

\section{References:}

[1] Ahluwalia J.S. (1998), Total Quality Management, New Delhi, India

[2] Bardzil P. \& Slaski M. (2003), "Emotional Intelligence: Fundamental Competencies for Enhanced Service Provision", Managing Service Quality-13(2) pp.97-104

[3] Cavelzanl et al (2005), Emotional Intelligence and Hotel Business, University of Milan, Switzerland, pp.88-101

[4] Deadrick L. D. \& Bruce R. M. (2001), "Service with a Smile, Legal and Emotional Issues", Journal of Quality Management-6(1) pp.99-110.

[5] Heskett, James L., W. Earl Sasser, Jr., and Leonard A. Schlesinger (1997), Service Profit Chain New York: Free Press.

[6] Kernbach \& Schutte (2005), "The Impact of Service Provider Emotional Intelligence on Customer Satisfaction", Journal of Marketing-19(7) pp. 438-444

[7] Kiely, J. (2005), "Emotions in Business-to-Business Service Relationships”, The Service Industries Journal-25(3) pp. 373-390

[8] Langhorn, S. (2008), The Role of Emotions in Service Business, pp. 221-224

[9] Scheider, B., S. S. White, et al. (1998) "Linking Service Climate and Customer Perceptions of Service Quality: Test of a Causal Model", Journal of Applied Psychology, Vol. 83 No.2 pp.150-163.

[10] Schneider B, Parkington J.J. \& Buxton M.V. (1980), "Employee and Customer Perceptions of Services in Banks", Administrative Science Quarterly-25(2) pp.256-265

[11] Schneider, B and D.E. Bowen (1993), "Human Resource Management Is Critical”, Organizational Dynamics, pp. $39-52$.

[12] Susan \& Pappas (2007), "Emotional Intelligence, Its Measurement and Implications for the Workplace", International Journal of Management Reviews 9(4) pp.01-23

[13] Varca E.P. (2004), "Service Skills for Service Workers: Emotional Intelligence and Beyond”, Managing Service Quality-14(6) pp.457-467

[14] Zeidner et al (2004), "Emotional Intelligence in the Workplace: A Critical Review", Applied Psychology: an International Review 53(3) pp.371-399. 